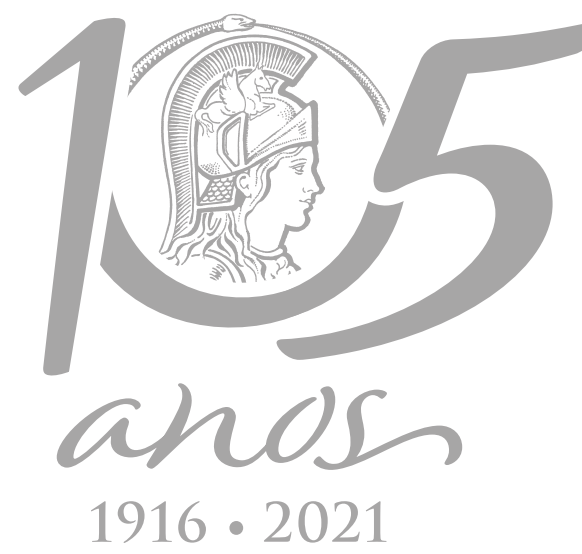

\title{
Antarctic environments as a source of bacterial and fungal therapeutic enzymes
}

\author{
IGOR G.O. LIMA, JAMES R.S. BISPO, ADSON Y.H. AGOSTINHO, ALINE C. DE \\ QUEIROZ, MAGNA SUZANA A. MOREIRA, MICHEL RODRIGO Z. PASSARINI, VALÉRIA \\ M. DE OLIVEIRA, LARA D. SETTE, LUIZ HENRIQUE ROSA \& ALYSSON WAGNER F. \\ DUARTE
}

\begin{abstract}
Microbial therapeutic enzymes are the protagonists in the pharmacological treatment of different human diseases. The intrinsic enzymatic characteristics, such as high affinity and specificity to the corresponding substrate, enable effective therapies, with minimal adverse effects and complete remission. However, immunogenicity, short half-life, low enzymatic yield, and low selectivity regarding available enzyme drugs are currently the main obstacles to their development and the broad adherence to therapeutic protocols. By harboring adapted and still unexplored microbial life, environments of extreme conditions, such as Antarctica, become especially important in the prospecting and development of new enzymatic compounds that present higher yields and the possibility of genetic improvement. Antarctic microorganisms have adaptation mechanisms, such as more fluid cell membranes, production of antifreeze proteins and enzymes with more malleable structures, more robust, stable, selective catalytic sites for their respective substrates, and high antioxidant capacity. In this context, this review aims to explore enzymes synthesized by bacteria and fungi from Antarctica as potential drug producers, capable of providing therapeutic efficacy, less adverse effects, and lower production costs with highlight to L-Asparaginase, collagenase, superoxide dismutase and ribonucleases. In addition, this review highlights the unique biotechnological profile of these Antarctic extremophile microorganisms.
\end{abstract}

Key words: Antarctica, collagenase, extremophiles, L-Asparaginase, superoxide dismutase, therapeutics enzymes.

\section{INTRODUCTION}

The unexplored frozen Antarctica continent is a source of complex habitats for the development of different microbial species, including fungi, bacteria, and yeasts (Bowman 2018). In an environment with harsh and extreme characteristics, such as temperatures reaching $-80^{\circ}$ to $-93.2^{\circ} \mathrm{C}$ in winter (Parker 2014, NúñezMontero \& Barrientos 2018); strong and constant winds close to the surface (Turner et al. 2009); frequent freeze-thaw cycles forming thaw lakes with varying salinity; precipitation, low humidity, and desert regions (Bowman 2018); high incidence of ultraviolet (UV) radiation due to depletion of the ozone layer associated with reflection in the ice (Marizcurrena et al. 2017), in addition to the low nutrient availability (Yergeau et al. 2006), survival becomes a challenge for these microorganisms. Nevertheless, many microorganisms can thrive in this environment and a huge Antarctica microbial diversity are being revealed either by culture and unculture dependent methods (Duarte et al. 2016, Pulschen et al. 2017, Wentzel et al. 2019, Ogaki et al 2020). 
According to Duarte et al. (2018a) the growing number of new microbial taxa from Antarctica indicates an apparently hidden diversity in this environment.

The adaptation to the Antarctic environmental conditions is characteristic of microorganisms classified as extremophiles since they are able to develop mechanisms to deal with the "extremes" imposed by the environment. Extremophilic microorganisms are a rich source of enzymes resistant to high (thermophilic) and low (psychrophilic) temperatures, salinity (halophilic), $\mathrm{pH}$ variations (alkalophilic and acidophilic), and UV radiation (Thomas \& Dieckmann 2002). Concerning the psychrophilic microorganisms, those able to develop in environments with extreme cold, the synthesis of glycoproteins and antifreeze peptides prevents the crystallization of intracellular water, which is lethal to the cells (Morozkina et al. 2010).

The capacity to produce biomolecules with high biotechnological value explains why Antarctica has been the focus of researches related to isolation, bioprospecting, and application of microbial biomolecules in different sectors, including food, cosmetics, and pharmaceutical industries. In this sense, this review describes the Antarctic microbial enzymes with biotechnological potential for the development of new drugs and/or therapies, aiming at the reduction of adverse effects, lower production costs, and greater therapeutic efficacy.

\section{THERAPEUTIC POTENTIAL OF THE ANTARCTIC PSYCHROPHILIC ENZYMES: STRUCTURAL AND MOLECULAR PERSPECTIVE}

The application of microbial therapeutic enzymes has revolutionized the struggle against numerous human diseases. The intrinsic enzymatic characteristics, such as high affinity and specificity to the corresponding substrates, enable effective therapies, with minimal adverse effects and complete remission (Zhou et al. 2021). Although they offer too many benefits, there are still obstacles to be overcome including immunogenicity, short half-life, and low selectivity regarding the drugs currently available on the market (Bax 2020).

The bioprospecting, in turn, has become the main alternative to the search for enzymes with different catalytic profiles and that meet the pharmacological demand. For this reason, psychrophilic microorganisms, especially those living in the Antarctic regions, emerge as potential sources, due to the need for adaptive mechanisms developing to inhabit this extreme environment. These adaptations correspond to specific genetic changes, which are a consequence of long-term selection, expressed in the form of structural changes in cellular components (Sarmiento et al. 2015).

It is known that, at low temperatures, the kinetic energy available is insufficient to achieve the energy needed for rearrangements in the conformational factors related to catalysis in mesophilic organisms (Martorell et al. 2019). Furthermore, proteins often tend to undergo denaturation processes, as the availability of water molecules greatly decreases since they become more orderly and less associated with proteins (Sarmiento et al. 2015). Cold adapted enzymes, however, overcome these energy 
barriers through very diverse structural and molecular solutions (Mangiagalli et al. 2021).

Active sites of psychrophilic enzymes are robust and have greater accessibility to the substrate, resulting in low energy costs during protein-ligand conjugation (Ashok et al. 2019). Regarding the energetic perspective of the system, a decrease in enthalpy is observed, caused by the reduction in the number of interactions that must be broken during the transition from the basic enzyme-substrate complex to the transition state (activated complex) of the reaction (Santiago et al. 2016). Thus, the activation energy of the reactions is considerably lower, when compared to that of the mesophilic and thermophilic counterparts. On the other hand, to compensate for the lower enthalpy, there is an increase in entropy due to the change in the stability, as well as the increase in structural protein flexibility (Santiago et al. 2016, Bruno et al. 2019). Together, these characteristics contribute to the main adaptative attribute inherent to cold enzymes, the high catalytic rate at low temperatures (Yang et al. 2021). In pharmacological application, the high enzymatic activity translates into smaller amounts of the drug to obtain the same results as its counterparts, under ideal conditions, and, therefore, the patient will be preserved from receiving high doses.

Several specific compositional adaptations and secondary, tertiary, and/or quaternary structural properties are identified in these polypeptides (Figure 1) aiming to achieve sufficient conformational flexibility (Siddiqui et al. 2013). They show a decreased central hydrophobicity, however, with an increased surface hydrophobicity and, thus, a greater presence of nonpolar residues in the external protein structure (Martorell et al. 2019). The content of larger $\alpha$-helices at the expense of $\beta$-sheets is a fundamental and determinant characteristic of malleability (Jin et al. 2019). The percentage of proline residues is higher in $\alpha$-helices, but in loops, they tend to be reduced (Siddiqui et al. 2013). It is also worth noting the predilection for small amino acids in the enzymatic constitution, such as Ala (alanine),

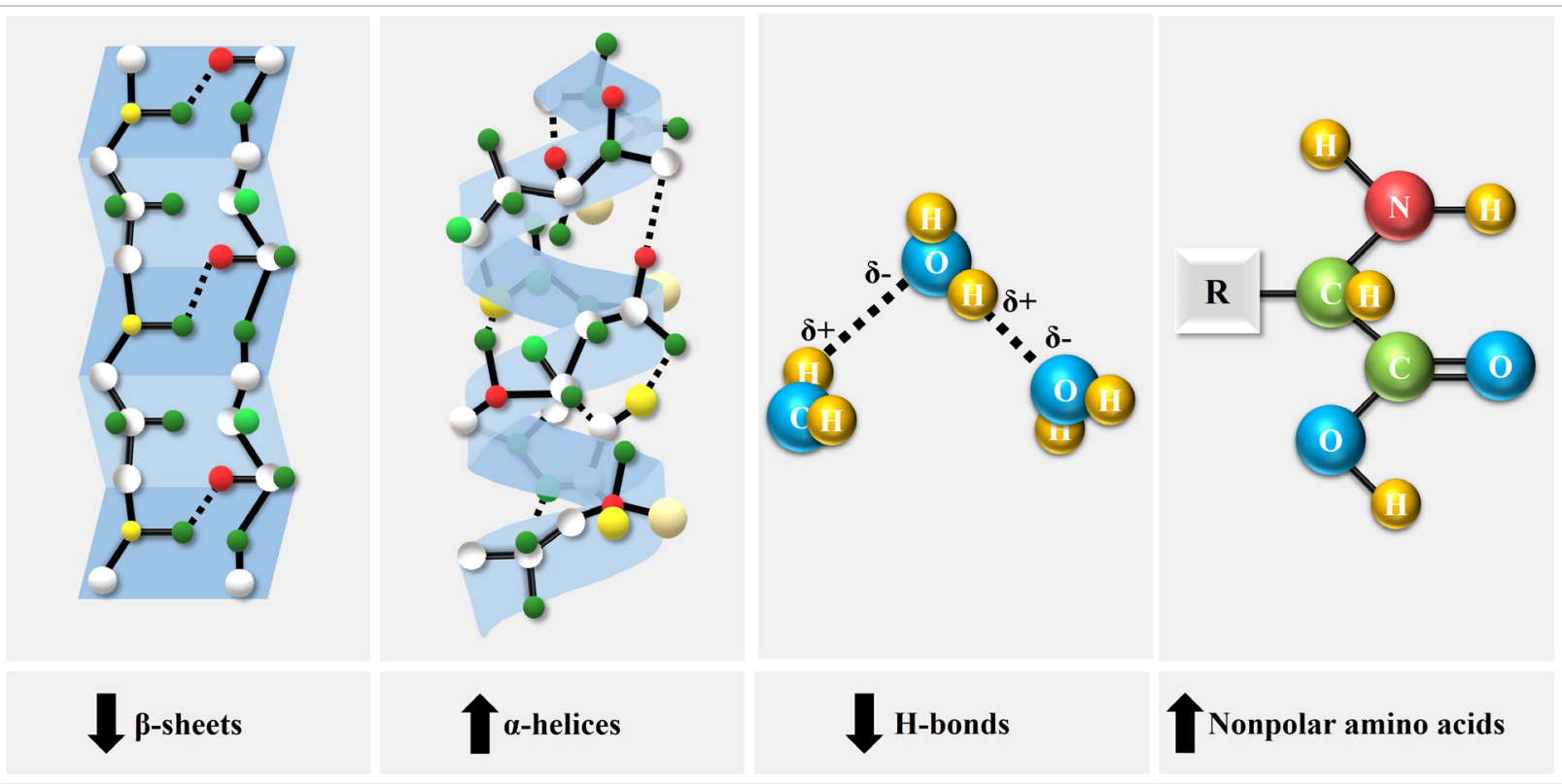

Figure 1. Structural and molecular adaptations of the enzymes produced by cold-adapted microorganisms. 
Asp (aspartate), Gly (glycine), Ser (serine), and Thr (threonine); lower arginine/lysine ratio and higher glutamate + aspartate/arginine + lysine ratio compared to mesophilic counterparts (Bruno et al. 2019, Yang et al. 2021).

From a therapeutic perspective, the different amino acid composition of these enzymes gives a wider range of epitopes and, consequently, produces different immunogenicity profiles of the marketed enzymatic drugs. It is emphasized that these characteristics point to a promising scenario, with more effective treatments and few adverse effects, especially in immunological bias, by reducing hypersensitivity reactions (Ghosh et al. 2019).

Notably, cold-active proteins have weaker molecular interactions, such as interdomain and intersubunit interactions, fewer disulfide bridges, and reduced electrostatic interactions (e.g. H-bonds, salt bridges, cation-pi interactions, aromatic-aromatic interactions) (Siddiqui et al. 2013). In contrast to the decrease in secondary structures and oligomerization, there is an increase in the number and size of the loops. In addition to contributing to increased flexibility, these particularities are usually related to the attenuation of stability (Bruno et al. 2019). Nevertheless, studies have shown that thermolability, although frequent in these polypeptides, is not universal. Antarctic bacteria Pseudoalteromonas haloplanktis TAC125, for example, produced GroEL and thioredoxin with thermostability similar to the Escherichia coli (Parrilli \& Tutino 2017). Therefore, the plurality of attributes inherent to the Antarctic extremozymes stands out, and they can even natively display the combination of the various profiles desired by the pharmaceutical industry in just one protein.

Different enzymes (L-asparaginase, collagenase, superoxide dismutase, and ribonucleases) produced by microorganisms of Antarctica are described below. In this review, the attention was given to enzymes that presented a good biotechnological profile and had their activity and enzymatic profile evaluated, in addition to characteristics that made them potential targets for biotechnological development and application in innovative therapies in the health area. Data related to the enzymes and the producer microorganisms are shown in Tables I and II.

\section{L-ASPARAGINASE}

L-asparaginase (L-asparagine amidohydrolase, L-ASNase, E.C.3.5.1.1) is a chemotherapeutic drug listed as an essential drug by the World Health Organization (WHO) (Beckett \& Gervais 2019). The incorporation of this enzyme in the treatment of Acute Lymphocytic Leukemia (ALL) increased the complete remission of the disease from 20 to $80-90 \%$, configuring, therefore, as an indispensable medicine to face the respective neoplasia (Costa-Silva et al. 2020). Besides, it is emphasized the role of L-ASNase in therapeutic protocols for acute myelocytic leukemia, lymphosarcoma, acute myelomonocytic leukemia, reticulosarcoma, and melanosarcoma (Golbabaie et al. 2020).

The antineoplastic mechanism of L-ASNase comes from the inherent ability to catalyze the conversion of the amino acid L-asparagine (L-Asn) to L-aspartate (L-Asp) and ammonia (Golbabaie et al. 2020). In contrast to healthy cells, the expression of asparagine synthase, an enzyme responsible for producing L-Asn in the intracellular medium, is low in neoplastic cells. Thus, the maintenance of tumor metabolism depends on extracellular sources of the respective amino acid. The biopharmaceutical, by decreasing the patient's serum L-asparagine levels, causes a nutritional restriction in the 
Table I. Characteristics of therapeutic enzymes produced by Antarctic bacteria and fungi.

\begin{tabular}{|c|c|c|c|c|c|c|c|}
\hline Enzyme & Microorganism & Site and source & $\begin{array}{c}\text { Optimum } \\
\text { temperature } \\
\left({ }^{\circ} \mathrm{C}\right)\end{array}$ & $\begin{array}{c}\text { Optimum } \\
\mathrm{pH}\end{array}$ & $\begin{array}{l}\text { Enzymatic } \\
\text { activity }\end{array}$ & $\begin{array}{l}\text { Specific } \\
\text { activity } \\
\left(\text { U.mg-1) }^{-1}\right)\end{array}$ & Reference \\
\hline \multirow[t]{14}{*}{ L-asparaginase } & $\begin{array}{l}\text { Leucosporidium } \\
\text { muscorum CRM } 1648\end{array}$ & $\begin{array}{c}\text { Marine sediments } \\
\text { (Admiralty Bay } \\
\text { - King George } \\
\text { Island) }\end{array}$ & NC & NC & NC & NC & $\begin{array}{l}\text { Freire et } \\
\text { al. (2020) }\end{array}$ \\
\hline & $\begin{array}{l}\text { Leucosporidium } \\
\text { scottii L115 }\end{array}$ & $\begin{array}{c}\text { Marine sediments } \\
\text { (Antarctic } \\
\text { Peninsula) }\end{array}$ & NC & NC & NC & NC & $\begin{array}{l}\text { Moguel et } \\
\text { al. (2020) }\end{array}$ \\
\hline & $\begin{array}{l}\text { Leucosporidium } \\
\text { scottii L120 }\end{array}$ & $\begin{array}{l}\text { Seafloor } \\
\text { sediments } \\
\text { (Antarctic } \\
\text { environment) }\end{array}$ & NC & NC & $\begin{array}{l}1.1 \times 10^{-3} \\
\text { U.mg-1 }\end{array}$ & NC & $\begin{array}{l}\text { Correa et } \\
\text { al. (2020) }\end{array}$ \\
\hline & $\begin{array}{l}\text { Cryptococcus } \\
\text { victoriae L92 }\end{array}$ & $\begin{array}{c}\text { Seafloor } \\
\text { sediments } \\
\text { (Antarctic } \\
\text { environment) }\end{array}$ & NC & NC & $\begin{array}{l}0.9 \times 10^{-3} \\
\text { U.mg }\end{array}$ & NC & $\begin{array}{l}\text { Correa et } \\
\text { al. (2020) }\end{array}$ \\
\hline & $\begin{array}{c}\text { Trichosporon asahii } \\
\text { IBBLA1 }\end{array}$ & $\begin{array}{c}\text { Schirmacher Hills } \\
\text { (Dronning Maud } \\
\text { Land) }\end{array}$ & NC & NC & $\begin{array}{l}20.57 \\
\text { U. } \mathrm{mL}^{-1}\end{array}$ & NC & $\begin{array}{l}\text { Ashok et } \\
\text { al. (2019) }\end{array}$ \\
\hline & $\begin{array}{c}\text { Coprinopsis cinerea } \\
\text { IBBLA4 }\end{array}$ & $\begin{array}{c}\text { Schirmacher Hills } \\
\text { (Dronning Maud } \\
\text { Land) }\end{array}$ & NC & NC & $\begin{array}{l}16.23 \\
\text { U. } \mathrm{mL}^{-1}\end{array}$ & NC & $\begin{array}{l}\text { Ashok et } \\
\text { al. (2019) }\end{array}$ \\
\hline & $\begin{array}{c}\text { Cosmospora sp. } \\
\text { OB4B }\end{array}$ & $\begin{array}{l}\text { Whale bones } \\
\text { (King George } \\
\text { Island) }\end{array}$ & NC & NC & $\begin{array}{c}>0.4 \\
\text { U. } \mathrm{mL}^{-1}\end{array}$ & NC & $\begin{array}{l}\text { Duarte et } \\
\text { al. (2018) }\end{array}$ \\
\hline & $\begin{array}{c}\text { Cosmospora sp. } \\
\text { OB1B }\end{array}$ & $\begin{array}{l}\text { Whale bones } \\
\text { (King George } \\
\text { Island) }\end{array}$ & NC & NC & $\begin{array}{c}>0.2 \\
\text { U. } \mathrm{mL}^{-1}\end{array}$ & NC & $\begin{array}{l}\text { Duarte et } \\
\text { al. (2018) }\end{array}$ \\
\hline & Cosmospora sp. OB2 & $\begin{array}{l}\text { Whale bones } \\
\text { (King George } \\
\text { Island) }\end{array}$ & NC & NC & $\begin{array}{c}>0.2 \\
\text { U. } \mathrm{mL}^{-1}\end{array}$ & NC & $\begin{array}{l}\text { Duarte et } \\
\text { al. (2018) }\end{array}$ \\
\hline & Penicillium sp. C2 & $\begin{array}{l}\text { Sea star } \\
\text { (King George } \\
\text { Island) }\end{array}$ & NC & NC & $\begin{array}{c}>1.3 \\
\text { U.mL }\end{array}$ & NC & $\begin{array}{l}\text { Duarte et } \\
\text { al. (2018) }\end{array}$ \\
\hline & Penicillium sp. E2B & $\begin{array}{l}\text { Sea star } \\
\text { (King George } \\
\text { Island) }\end{array}$ & NC & NC & $\begin{array}{c}>0.4 \\
\text { U. } \mathrm{mL}^{-1}\end{array}$ & NC & $\begin{array}{l}\text { (Duarte et } \\
\text { al. 2018) }\end{array}$ \\
\hline & $\begin{array}{l}\text { Pseudogymnoascus } \\
\text { sp. S2B }\end{array}$ & $\begin{array}{l}\text { Salpa sp. } \\
\text { (King George } \\
\text { Island) }\end{array}$ & NC & NC & $\begin{array}{c}>0.2 \\
\text { U. } \mathrm{mL}^{-1}\end{array}$ & NC & $\begin{array}{l}\text { Duarte et } \\
\text { al. (2018) }\end{array}$ \\
\hline & Fungal sp. OB7A & $\begin{array}{l}\text { Whale bones } \\
\text { (King George } \\
\text { Island) }\end{array}$ & NC & NC & $\begin{array}{c}>0.5 \\
\text { U.mL }\end{array}$ & NC & $\begin{array}{l}\text { Duarte et } \\
\text { al. (2018) }\end{array}$ \\
\hline & Fungal sp. L2-16A & $\begin{array}{l}\text { Lichen } \\
\text { (King George } \\
\text { Island) }\end{array}$ & NC & NC & $\begin{array}{c}>0.1 \\
\text { U. } \mathrm{mL}^{-1}\end{array}$ & NC & $\begin{array}{l}\text { Duarte et } \\
\text { al. (2018) }\end{array}$ \\
\hline
\end{tabular}


Table I. Continuation.

\begin{tabular}{|c|c|c|c|c|c|c|c|}
\hline Collagenase & Arthrobotrys tortor & Antarctica & NC & NC & NC & NC & $\begin{array}{c}\text { Tosi et al. } \\
\text { (2002) }\end{array}$ \\
\hline $\begin{array}{c}\text { Superoxide } \\
\text { Dismutase }\end{array}$ & $\begin{array}{c}\text { Pseudoalteronomas } \\
\text { haloplanktis }\end{array}$ & $\begin{array}{c}\text { Marine sediments } \\
\text { (Antarctica) }\end{array}$ & 25 & 6.9 & NC & $14.10^{3}$ & $\begin{array}{c}\text { Castellano } \\
\text { et al. } \\
\text { (2006) }\end{array}$ \\
\hline & $\begin{array}{c}\text { Marinomonas sp. } \\
\text { NJ522 }\end{array}$ & $\begin{array}{c}\text { Sea ice in } \\
\text { Antarctic }\end{array}$ & 40 & 9.0 & NC & 148.0 & $\begin{array}{c}\text { Zheng et } \\
\text { al. (2015) }\end{array}$ \\
\hline & $\begin{array}{c}\text { Aspergillus glaucus } \\
363\end{array}$ & $\begin{array}{c}\text { Livingston Island } \\
\text { (Antarctica) }\end{array}$ & 25 & 7.0 & NC & 39.61 & $\begin{array}{c}\text { Tosi et al. } \\
\text { (2010) }\end{array}$ \\
\hline & $\begin{array}{c}\text { Penicillium sp. P14 } \\
\text { Penicillium sp. M12 }\end{array}$ & $\begin{array}{c}\text { Antarctic soils } \\
\text { Antarctic soils }\end{array}$ & 10 & 7.8 & NC & NC & $\begin{array}{c}\text { Gocheva } \\
\text { et al. } \\
\text { (2006) }\end{array}$ \\
\hline Ribonuclease & $\begin{array}{c}\text { Pseudomonas } \\
\text { fluorescens 10CW }\end{array}$ & $\begin{array}{c}\text { Schirmacher } \\
\text { Oases (Antarctica) }\end{array}$ & 40 & 7.4 & NC & NC & $\begin{array}{c}\text { Gocheva } \\
\text { et al. } \\
\text { (2006) }\end{array}$ \\
\hline
\end{tabular}

tumor and, consequently, activates apoptotic mechanisms (Chand et al. 2020, Borges et al. 2020).

Despite the enormous therapeutic importance, too many adverse effects prevent its prolonged use and, even, the administration in a significant portion of the population. Pancreatitis, hyperglycemia, bronchospasm and coagulation disorders, leading to intracranial thrombosis or hemorrhage, are recurrent side effects, which are related to the catalytic activity adjacent to the amino acid L-glutamine present in the current commercialized L-asparaginases (Cecconello et al. 2020). However, the main limitation to therapy is the high immunogenicity, causing hypersensitivity reactions between 30 and $75 \%$ of individuals submitted to the native enzymatic form of E. coli, and approximately 70\% develop anti-EcAll antibodies (González-Torres et al. 2020).

According to Lopes et al. (2017) due to its importance in the treatment of several types of cancers, in particular leukemia, the searcher for new microbial sources of L-ASNase can drive the increase in its availability and in the reduction of side effects. In this sense, extremophile isolates, whose adaptive mechanisms produce amidohydrolases with different profiles, have become an extremely promising alternative. Antarctica is emerging in this area, as it is characterized by being a cradle of extremophilic microbial biodiversity.

The yeast Leucosporidium muscorum CRM 1648, isolated from marine sediments from Admiralty Bay, King George Island, Antarctica, produced an L-ASNase devoid of glutaminase activity. The respective strain was able to produce 490.41 U.L-1 of L-ASNase, resulting in a volumetric productivity of $5.12 \mathrm{U} . \mathrm{L}^{-1} \cdot \mathrm{h}^{-1}$ (Freire et al. 2020). The L-asparaginases available on the market for chemotherapy use come from two Gram-negative bacteria, E. coli and Erwinia chrysanthemi. Nonetheless, yeast and fungal enzymes are expected to have less immunogenicity, since, being eukaryotic, they are evolutionarily closer to humans compared to bacteria (Chand et al. 2020). Moreover, yeast ASNase demonstrated better serum stability and optimal pH close to physiological conditions (Moguel et al. 2020). 
Table II. Characteristics of the Antarctic therapeutic enzymes produced by heterologous expression.

\begin{tabular}{|c|c|c|c|c|c|c|c|}
\hline Enzyme & Microorganism & $\begin{array}{l}\text { Isolation } \\
\text { source }\end{array}$ & $\begin{array}{l}\text { Optimum } \\
\text { temperature } \\
\left({ }^{\circ} \mathrm{C}\right)\end{array}$ & $\underset{\mathrm{pH}}{\text { Optimum }}$ & $\begin{array}{l}\text { Enzymatic } \\
\text { activity }\end{array}$ & $\begin{array}{l}\text { Specific } \\
\text { activity }\end{array}$ & Reference \\
\hline \multirow[t]{2}{*}{$\begin{array}{l}\text { Superoxide } \\
\text { Dismutase } \\
\text { (GMO) }\end{array}$} & $\begin{array}{l}\text { Pseudoalteromonas } \\
\text { sp. ANT506 }\end{array}$ & $\begin{array}{l}\text { Antarctic } \\
\text { sea-ice }\end{array}$ & 30 & 8.0 & NC & $\begin{array}{l}587.4 \\
\text { U.mg-1 }\end{array}$ & $\begin{array}{l}\text { Wang et al. } \\
\text { (2015) }\end{array}$ \\
\hline & $\begin{array}{l}\text { Rhodotorula } \\
\text { mucilaginosa AN5 }\end{array}$ & $\begin{array}{l}\text { Antarctic } \\
\text { sea-ice }\end{array}$ & 20 & 3.0 & NC & $\begin{array}{l}92.11 \\
\text { U.mg-1 }\end{array}$ & $\begin{array}{l}\text { Kan et al. } \\
\text { (2017) }\end{array}$ \\
\hline $\begin{array}{l}\text { Ribonuclease } \\
\text { (GMO) }\end{array}$ & $\begin{array}{l}\text { Psychrobacter sp. } \\
\text { ANT206 }\end{array}$ & $\begin{array}{l}\text { Antarctic } \\
\text { sea-ice }\end{array}$ & 30 & 6.0 & NC & $\begin{array}{c}115.60 \\
\mu \mathrm{mol}^{-1} . \\
\mathrm{min}^{-1} \\
\mathrm{mg}^{-1}\end{array}$ & $\begin{array}{l}\text { Wang et al. } \\
\text { (2019) }\end{array}$ \\
\hline
\end{tabular}

Moguel et al. (2020) reported the synthesis of this amidohydrolase by a psychrotolerant microorganism isolated from marine sediments, Antarctic Peninsula. The yeast Leucosporidium scottii L115, under suitable process conditions, reached an enzymatic productivity of 35.11 U.L-1. $h^{-1}$, a value high enough to develop scale-up studies. Correa et al. (2020) also described an L-ASNase from the eukaryote L. scotti. The L120 strain, collected from seafloor sediments of the Antarctic environment, showed an enzyme with catalytic activity equal to $1.1 \mathrm{U}^{\mathrm{g}} \mathrm{g}^{-1}$. The same study reported the Antarctic strain of Cryptococcus victoriae $L 92$ as a producer of an L-ASNase with an activity of $0.9 \mathrm{U} . \mathrm{g}^{-1}$.

Ashok et al. (2019) identified 30 filamentous fungi isolated from Schirmacher Hills, in Antarctica, as producers of L-asparaginases. Among them, Trichosporon asahii IBBLA1 showed the highest enzymatic activity, followed by Coprinopsis cinerea IBBLA4, with maximum activities of 20.57 U. $\mathrm{mL}^{-1}$ and 16.23 U. mL-1, respectively. The parameters used to achieve the optimal enzymatic activity were temperature of $30{ }^{\circ} \mathrm{C}$ and neutral $\mathrm{pH}$ (7.0). These values are auspicious, pointing to potential development in the pharmacological area. In addition, it is necessary to highlight that the L-ASNases produced by the aforementioned fungi did not present activities for the nitrogen sources glutamine and urea (Ashok et al. 2019).

These characteristics are extremely relevant, especially in the current therapeutic scenario, whose main adverse effects of the enzyme drug are caused by the low selectivity for the acting substrate, L-asparagine, being, therefore, capable of hydrolyzing other nitrogen compounds (Beckett \& Gervais 2019). Thereby, the high biotechnological value of Antarctic L-ASNases is corroborated, with the potential to masterfully replace current preparations, offering greater efficacy in treatment, fewer side effects, and, possibly, lower productive and commercial costs.

Furthermore, studies prove the wide therapeutic capacity of L-ASNase from filamentous fungi to act in different conditions. The fungal species Purpureocillium lilacinum, for example, demonstrated antimicrobial activity against a range of bacteria: Pseudomonas aeruginosa, Klebsiella pneumoniae, Salmonella typhimurium, Proteus vulgaris, Staphylococcus aureus, and Listeria monocytogenes. It should be noted that this enzyme obtained a minimum 
inhibitory concentration (MIC) against P. vulgaris equal to $21.06 \mathrm{mg} \cdot \mathrm{mL}^{-1}$ (Vimal \& Kumar 2020). Such results are important since the acquisition of new drugs to treat infections is highly desired, especially in the advent of the era of antibiotic resistance.

A total of eight filamentous fungi isolated from samples collected on King George Island exhibited L-ASNase activity in liquid medium. Three of them were identified as Cosmospora sp. (isolated from whale bones: OB4B, OB1B, and OB2), two as Penicillium sp. (recovered from sea star: C2 and E2B), and one Pseudogymnoascus taxa (recovered from Salpa sp.: S2B). Isolates OB7A (recovered from whale bones) and L2-16A (recovered from lichen) could not be identified. It is noteworthy that Penicillium sp. C2 and the unidentified fungus OB7A showed the highest enzymatic activities. The first presented L-ASNase activity > $1.3 \mathrm{U} \cdot \mathrm{mL}^{-1}$ and the second > 0.5 U. $\mathrm{mL}^{-1}$ (Duarte et al. 2018b).

\section{COLLAGENASE}

Collagen is a protein composed of a triple helix structure. However, its rigidity makes it undegradable to most proteases, reacting only to collagenases (Microbial collagenase, E.C. 3.4.24.3) (De Albuquerque Wanderley et al. 2020). The applications of collagenolytic enzymes are vast, especially in the medical and pharmaceutical segments. The enzyme produced by Clostridium histolyticum has been approved by the Food and Drug Administration (FDA) for use as a drug in the treatment of Dupuytren's disease, characterized by abnormal tissue thickening due to exacerbated collagen deposition (Cooper et al. 2020). This enzyme is also used in the wound healing and burns (Alipour et al. 2016).

Additionally, the use of collagenase from Clostridium histolyticum $(\mathrm{CCH})$ as a first-line treatment in Peyronie's disease (PD) has increased substantially (Gabbrielson et al. 2017). PD manifests itself as a penile abnormality, expressed by fibrosis of the tunica albuginea, causing penile curvature and deformity, penile pain, and sexual dysfunction (Hatfield et al. 2020). Although surgical treatment is the most common, there is a gradual inversion of this scenario, with the rise of injection therapies, aiming, above all, to minimize the following adverse effects of application: shortening of the penis, change in penile sensation, erectile dysfunction, and palpable sutures (Sukumar et al. 2020).

Given the therapeutic importance, the search for even more effective collagenases is undoubtedly encouraged. Nevertheless, the present study recovered only one scientific manuscript referring to the collagenolytic protease produced constitutively by an Antarcticderived microorganism, the fungus Arthrobotrys tortor (Tosi et al. 2002). Therefore, the need for investments in the field of bioprospecting of this enzyme is emphasized, in order to develop collagenases with different profiles and increase the scope of its action and pharmacological application.

\section{SUPEROXIDE DISMUTASE (SOD)}

Reactive oxygen species (ROS) are a set of oxygen free radicals that include superoxide $\left(\cdot \mathrm{O}_{2}^{-}\right)$, hydroxyl $\left(\mathrm{OH}^{\cdot}\right)$, peroxyl $\left.\left(\mathrm{RO}_{2}\right)^{\prime}\right)$, and hydroperoxyl $\left(\mathrm{HO}_{2} \cdot\right)$ radicals, and certain nonradical oxidizing agents, such as hydrogen peroxide $\left(\mathrm{H}_{2} \mathrm{O}_{2}\right)$ (Bayir 2005). ROS are important for several physiological mechanisms such as the synthesis of molecular structures and participation in body's defense system against pathogens (Pizzino et al. 2017). When there is an imbalance between the production of ROS and 
that of enzymes that metabolize them, oxidative stress occurs. These ROS attack other molecules such as carbohydrates, proteins, lipids, and the DNA itself, causing changes in their molecular structure and function, being studied as factors that cause cancer, degenerative diseases, cardiac disorders and is related to the aging process (Dalton et al. 1999, Rowe et al. 2008). In response to this scenario of oxidative stress, superoxide dismutase (Superoxide dismutase, SOD, E.C.1.15.1.1) appear to play a fundamental role in reducing these reactive oxygen species.

SODs are enzymes that incorporate a metal as a cofactor in its structure (metalloenzymes) responsible for the degradation of superoxide radicals $\left(\mathrm{O}_{2}^{-}\right)$in hydrogen peroxide $\left(\mathrm{H}_{2} \mathrm{O}_{2}\right)$, which is also a ROS, later degraded by catalase (Zheng et al. 2006). They are classified into 4 types according to the metal associated with the enzyme: Cu/Zn-SOD (copper and zinc), Mn-SOD (manganese), Fe-SOD (iron) and Ni-SOD (nickel). $\mathrm{Cu} / \mathrm{Zn}-\mathrm{SOD}$ is found in several organisms, being isolated from the periplasm of bacterial species. Studies demonstrate its role in the virulence of bacterial strains, being the main line of defense against erythrocyte SOR (Kim et al. 2010). MNSOD is found in prokaryotes and in eukaryotic mitochondria, where they are responsible for eliminating ROS, especially the superoxide formed during the respiratory chain (Candas \& Li 2014). Fe-SOD, found mainly in prokaryotes and chloroplasts, has shown interesting studies in its role in joint therapy against cancer, eliminating the ROS of cancer cells (Bafana et al. 2011a). Little reported in the literature, in a 1996 study, $\mathrm{Ni}$-SOD was isolated from strains Streptomyces sp. IMSNU-1 and Streptomyces coelicolor ATCC 10147 (Youn et al. 1996).

Enzymatic antioxidants are widely used to combat ROS due to various factors such as bioavailability, specificity, and non-consumption during the antioxidant reaction, with SOD and catalase being among the most potent antioxidants found in nature (Ratnam et al. 2006). Studies point out the importance of using and increasing the expression of SODs in cancer treatments (Hu et al. 2005), urinary bladder cystitis by pelvic irradiation (Kanai et al. 2002), rheumatoid arthritis (Goebel \& Storck1983), progressive systemic sclerosis (Morita et al. 1996), skin inflammation (Kwon et al. 2012), vitiligo (Jain et al. 2011), among other potential applications.

Psychrophilic or psychrotolerant microorganisms have small rates of metabolism, with less use of ATP and consequent accumulation of electrons in their production process, with an increase in the production of Reactive Oxygen species (ROS), such as superoxide radicals (.O2) (Gocheva et al. 2006). In addition to this mechanism, exposure of oxygen to UV radiation or chemical reducers such as oxidases, peroxidases, and mono- and dihydrooxygenases also increase the production of ROS (Xie et al. 2009). In order to combat this excess of ROS, these microorganisms develop differentiated physiological processes, with consequent production of SODs of high biotechnological value (Brenchley 1996).

From the group of SOD-producing bacteria isolated from the Antarctic environment, Zheng et al. (2006) worked with the species Marinomonas sp. NJ522 isolated from the icy Antarctic sea between 2001 and 2002. Characterized as belonging to the Fe-SOD group, this enzyme showed a specific activity of $148 \mathrm{U} \cdot \mathrm{mg}^{-1}$ protein and a purification of approximately 39 -fold with a yield of $9 \%$. Despite being produced by a psychrophilic bacterium, the optimal temperature of this SOD was $40^{\circ} \mathrm{C}$, which leaves it in a range of activity similar to that of the human organism, a characteristic that may indicate a biotechnological potential 
for the development of new antioxidant drugs (Zheng et al. 2006).

In another study, Castellano et al. (2006) worked with Pseudoalteromonas haloplanktis TAK125 isolated in 1992 from marine sediments collected near the French Antarctic Station Dumont d'Urville, which was able to produce a psychrophilic superoxide dismutase denominated PhSOD (Birolo et al. 2000). PhSOD showed a specific activity of $14.000 \mathrm{U} \cdot \mathrm{mg}^{-1} \cdot \mathrm{mol}$ $\mathrm{Fe}^{-1}$ mol subunit with a purification of 50 -fold. An interesting feature of this enzyme in the Fe-SOD group was that its specific activity practically did not vary over a wide range of temperature $\left(5-25^{\circ} \mathrm{C}\right)$ and $\mathrm{pH}$ (7.8-10.85), although new techniques are needed to confirmation of this profile. Although it is a psychrophilic enzyme, it showed a good resistance to thermal denaturation, reaching a denaturation/inactivation temperature of $30^{\circ} \mathrm{C}$ higher than the maximum growth temperature of P. haloplanktis TAK125 (Castellano et al. 2006). Considering the difficulties related to recombinant sources of SODs application in therapeutics due to problems related to availability and pharmacokinetics, enzymes with a more stable profile may emerge as perspectives for the future of the development of new antioxidant therapies (Bafana et al. 2011b).

Pseudoalteromonas sp. ANT506, a bacterium also isolated from the Antarctic seaice presented the production of a SOD (PSSOD) from the group of Fe-SODs with an interesting biotechnological profile. After the identification of the PSSOD encoding gene, it was inserted into E. coli and an rPSSOD enzyme was produced, which showed a specific activity of $587.4 \mathrm{U}^{\mathrm{mg}}{ }^{-1}$ protein and a 12.6 -fold purification, and $22.9 \%$ yield. Despite not having great thermal stability, characteristic of cold-adapted enzymes, this enzyme demonstrated stability in $\mathrm{pH}$ (7.09.0), and an important resistance to salinity, maintaining $62.4 \%$ of its optimal activity even in $2.5 \mathrm{M}$ of chloride sodium ( $\mathrm{NaCl}$ ) (Wang et al. 2016).

Kan et al. (2017) studied Rhodotorula mucilaginosa AN5, a cold-adapted yeast isolated from the Antarctic environment that produces Fe-SOD. The gene encoding this SOD was cloned and expressed in E. coli giving rise to the recombinant RmFeSOD. This enzyme demonstrated a specific activity of $92.11{\mathrm{U} . \mathrm{mg}^{-1}}^{-1}$ protein and a yield of $0.735 \mathrm{mg}$ SOD protein per gram of fresh weight. An interesting feature of RmFeSOD, was that it showed the highest stability in different $\mathrm{pH}$ ranges, when compared with other Fe-SOD, maintaining about $70 \%$ of its maximum activity in a $\mathrm{pH}$ range between 1.0 and 9.0 (Kan et al. 2017). This characteristic makes the RmFeSOD of $R$. mucilaginosa AN5 a potential enzyme for application in a wide range of functions, from pharmacological to food industry.

Filamentous fungi also stand out in the production of SODs with high biotechnological potential. Representatives of the psychrophilic and mesophilic Penicilium from the Antarctic soil, Penicillium sp. p14, and Penicillium sp. $\mathrm{m} 12$, respectively, were compared with another mesophilic strain isolated from a temperate region of Bulgaria (Penicillium sp. T35) regarding several aspects, among them, the production of SOD in different temperature ranges (Gocheva et al. 2006). Strains of Antarctic origin produced SODs with greater specific activity at lower temperatures, indicating the adaptation to oxidative stress, which is common in regions with extreme environmental characteristics such as Antarctica.

In another study, Tosi et al. (2010) evaluated the antioxidant activity of enzymes produced by filamentous fungus Penicillium sp. 161, Penicillium sp. p31, Cladosporium cladosporioides B611, Cladosporium oxysporum 
212, Epicoccum nigrum, and Aspergillus glaucus 363 isolated from soil collected near the permanent Bulgarian Antarctic base "St. Kliment Ohridski" on Livingston Island. Among them, A. glaucus 363 showed the highest antioxidant activity (specific activity of $39.61 \mathrm{U} \cdot \mathrm{mg}^{-1}$ protein) due to the production of SOD and catalase (Tosi et al. 2010). The SOD produced by A. glaucus 363 was characterized as a Cu/Zn-SOD, an enzyme with a fundamental role in the defense system of aerobic organisms against oxidative stress.

\section{RIBONUCLEASES}

Ribonucleases (Ribonucleases, RNases, EC 3.1.26.-) have several roles in the metabolism of RNA molecules. In addition to participating in the degradation of RNA molecules that are no longer useful, or with some type of damage, RNases actively participate in the maturation of RNA molecules and their transformation into alternative forms (Li \& Deutscher 2004). They are classified into 2 main groups, according to their RNA cleavage mechanism. Endoribonucleases are responsible for cleaving the phosphodiester bonds that bind ribonucleotides internally releasing fragments of RNA of various sizes. Among the endoribonucleases isolated in E. coli are RNases I, II, P, E, G, HI, and HII (Li \& Deutscher 2004). Exoribonucleases cleave RNA molecules generally from the $3^{\prime}$ or $5^{\prime}$ terminal position promoting the release of ribonucleotides that will participate in the formation of new RNA molecules (Nicholson 1999). In the group of exoribonucleases characterized in E. coli are RNases II, R, D, T, PH, BN, polynucleotide phosphorylase (PNPase), and oligoribonuclease (ORNase) (Li \& Deutscher 2004).

RNases have a key role in the regulation and maturation of DNA, being studied for their role in combating several diseases, in several species of organisms (Shruti et al. 2016). The bovine seminal vesicle RNase (BovineBS-RNase - EC.3.1.27.5) isolated from the Bos taurus species showed the potential to promote apoptosis of human thyroid cancer cells, becoming an alternative for the development of new antineoplastic drugs (Spalletti-Cernia et al. 2003). Enzymes from a species of the frog Rana pipiens from the RNase A family, Onconase and Amphinase, have shown great cytotoxic potential against several cancer cell lines (Ardelt et al. 2003, 2009, Singh et al. 2007). Bacteria are also an important source of isolation of RNases with anti-cancer activity. RNases from representatives of Bacillus intermedius presented apoptosis induction in ovarian cancer cells (Garipov et al. 2014). Bacillus amyloliquefaciens is a producer of barnase, an RNase with high cytotoxic power (Prior et al. 1996). Streptomyces aureofaciens is also a producer of cytotoxic RNase (Makarov et al. 2008). The search for microbial species that produce RNAs in environments with extreme characteristics such as Antarctica, generates the possibility of isolating RNAses with therapeutic activity, but which have a different profile of stability and potential for the development of new drugs

In the search for cold-adapted RNases, Reddy et al. (1994) worked with 13 species of psychrotrophic bacteria isolated from the soil of the region around Zub Lake, Schirmacher Oasis Antarctica (Shivaji et al. 1988). The bacterial extracts were exposed to a temperature of $65{ }^{\circ} \mathrm{C}$ for 30 minutes and immediately tested for enzymatic activity. Among the bacteria that showed thermolabile characteristics, the species Pseudomonas fluorescens showed a specific activity of $125 \mathrm{U}^{\mathrm{mg}} \mathrm{mg}^{-1}$ protein, with a purification of 36.8 -fold, and a yield of $14.7 \%$. Despite $P$. fluorescens demonstrating the ability to completely hydrolyze RNA from E. coli, when compared to bovine pancreatic RNase A, it 
demonstrated total inactivation at $65^{\circ} \mathrm{C}$ (Reddy et al. 1994).

RNase R was cloned from a Psychrobacter sp. ANT206 isolated from the Antarctic sea-ice and tested for its structure and catalytic properties (Wang et al. 2019). The PSRNR enzyme showed a specific activity of $115.60 \mu \mathrm{mol} . \mathrm{min}^{-1} \cdot \mathrm{mg}^{-1}$ with purification of 5.58 -fold, yield of $48.85 \%$, and maximum activity at $\mathrm{pH} 6.0$ and temperature of $30^{\circ} \mathrm{C}$. This enzyme was characterized as coldadapted and presented a salinity tolerance profile (Wang et al. 2019). Due to the characteristics of RNases R, degeneration of mRNAs and stable defective RNAs, and their importance for the expression of Shigella virulence genes and $E$. coli enteroinvasive strains (Cairrão et al. 2003), PsRNR appears as a promising alternative to antimicrobial treatments.

\section{CONCLUSIONS}

Enzymes produced by fungi and bacteria isolated from Antarctica have potential biotechnological value in therapeutics. The catalytic profile of these enzymes differs from the mesophilic counterparts, presenting greater specificity to their respective substrates, such as the L-asparaginases, which showed a lack of adjacent enzymatic activity. In addition to presenting peculiar molecular characteristics, psychrophilic polypeptides demonstrate potential compatibility with humans, whether due to temperature and $\mathrm{pH}$ similar to that of the human body or low immunogenicity. The studies that seek the isolation of superoxide dismutases and Antarctic L-asparaginases are growing. Considering the rich Antarctic ecosystem, it is possible to infer that there is a vast unexplored field in the search for microbial enzymes with biotechnological potential. Thus, it is concluded that the bioprospecting of Antarctic microorganisms is a promising alternative to the development of new enzymatic drugs, especially when looking at a market with different demands.

\section{Acknowledgments}

The authors acknowledge the financial support from Fundação de Amparo à Pesquisa do Estado de Alagoas-FAPEAL (60030 1074/2016), Conselho Nacional de Desenvolvimento Científico e Tecnológico (CNPq, 433388/2018-8 and 442258/2018-6), Coordenação de Aperfeiçoamento de Pessoal de Nivel Superior (CAPES) and Fundação de Amparo à Pesquisa do Estado de Minas Gerais (FAPEMIG). The scholarship for first author was supported by Conselho Nacional de Desenvolvimento Científico e Tecnológico (CNPQ - PIBITI 143722/2020-4). We would like to thank the parliamentarian Tereza Nelma da Silva Porto Viana Soares (Alagoas) for supporting the Brazilian Antarctic research. English review by Prof. Me. Jonatha Rodrigues da Silva.

\section{REFERENCES}

ALIPOUR H, RAZ A, ZAKERI S \& DJADID ND. 2016. Therapeutic applications of collagenase (metalloproteases): A review. Asian Pac J Trop Biomed 6(11): 975-981.

ARDELT B, ARDELT W \& DARZYNKIEWICZ Z. 2003. Cytotoxic ribonucleases and RNA interference (RNAi). Cell Cycle 2: $22-24$.

ARDELT W, ARDELT B \& DARZYNKIEWICZ Z. 2009. Ribonucleases as potential modalities in anticancer therapy. Eur J Pharmacol 625: 181-189.

ASHOK A, DORIYA K, RAO JV, QURESHI A, TIWARI AK \& KUMAR DS. 2019. Microbes Producing L-asparaginase free of glutaminase and urease isolated from extreme locations of Antarctic soil and moss. Sci Rep 9(1): 1-10.

BAFANA A, DUTT S, KUMAR A, KUMAR S \& AHUJA PS. 2011a. The basic and applied aspects of superoxide dismutase. J Mol Catal B-Enzym 68: 129 - 138.

BAFANA A, DUTT S, KUMAR S \& AHUJA PS. 2011b. Superoxide dismutase: an industrial perspective. Crit Rev Biotechnol 31: 65-76.

BAX BE. 2020. Erythrocytes as carriers of therapeutic enzymes. Pharmaceutics 12(5): 435.

BAYIR H. 2005. Reactive Oxygen Species. Crit Care Med 33: 498-501.

BECKETT A \& GERVAIS D. 2019. What makes a good new therapeutic L-asparaginase? World J Microbiol Biotechnol 35(10): 1-13. 
BIROLO L, TUTINO ML, FONTANELLA B, GERDAY C, MAINOLFI K, PASCARELLA S, SANNIA G, VINCI F \& MARINO G. 2000. Aspartate aminotransferase from the Antartica bacterium Pseudoalteromonas haloplanktis TAC 125. Cloning, expression, proporties and modelucar modelling. Eur J Biochem 267: 2790-2802.

BORGES GÁ, ELIAS ST, ARAUJO TSD, SOUZA PM, NASCIMENTOFILHO CHV, CASTILHO RM, SQUARIZE CH, MAGALHÃES PO \& GUERRA ENS. 2020. Asparaginase induces selective dose-and time-dependent cytotoxicity, apoptosis, and reduction of NFKB expression in oral cancer cells. Clin Exp Pharmacol Physiol 47(5): 857-866.

BOWMAN JS. 2018. Identification of microbial dark matter in Antarctic environments. Front Microbiol 9: 3165-3176.

BRENCHLEY JE. 1996. Psychrophilic microorganisms and their cold-active enzymes. I Ind Microbiol 17: 432-437.

BRUNO S, COPPOLA D, DI PRISCO G, GIORDANO D \& VERDE C. 2019. Enzymes from marine polar regions and their biotechnological applications. Mar Drugs 17(10): 544.

CAIRRÃO FC, CRUZ A, MORI H \& ARRAIANO CM. 2003. Cold shock induction of RNase $R$ and its role in the maturation of the quality control mediator SsrA/tmRNA. Mol Microbiol 50: 1349-1360.

CANDAS D \& LI JJ. 2014. MnSOD in oxidative stress responsepotential regulation via mitochondrial protein influx. Antioxid Redox Signal 20: 1599-1617.

CASTELLANO I, MARO AD, RUOCCO MR, CHAMBERY A, PARENTE A, MARTINO MTD, PARLATO G, MASULLO M \& VENDITTIS ED. 2006. Psychrophilic superoxide dismutase from Pseudoalteromonas haloplanktis: biochemical characterization and identification of a highly reactive cysteine residue. Biochimie 88: 1377-1389.

CECCONELLO DK, MAGALHÃES MRD, WERLANG ICR, LEE MLDM, MICHALOWSKI MB \& DAUDT LE. 2020. Asparaginase: An old drug with new questions. Hematol Transfus Cell Ther 42(3): 275-282.

CHAND S, MAHAJAN RV, PRASAD JP, SAHOO DK, MIHOOLIYA KN, DHAR MS \& SHARMA G. 2020. A comprehensive review on microbial L-asparaginase: Bioprocessing, characterization, and industrial applications. Biotechnol Appl Biochem 67(4): 619-647.

COOPER TB, POONIT K, YAO C, JIN Z, ZHENG J \& YAN H. 2020. The efficacies and limitations of fasciectomy and collagenase Clostridium histolyticum in Dupuytren's contracture management: a meta-analysis. J Orthop Surg 28(2): 2309499020921747.

CORREA HT, VIEIRA WF, PINHEIRO TMA, CARDOSO VL, SILVEIRA E, SETTE LD, PESSOA JUNIOR A \& FILHO UC. 2020. L-asparaginase and Biosurfactants produced by extremophile yeasts from Antarctic environments. Ind Biotechnol 16(2): 107-116.

COSTA-SILVA TA, COSTA IM, BIASOTO HP, LIMA GM, SILVA C, PESSOA A \& MONTEIRO G. 2020. Critical overview of the main features and techniques used for the evaluation of the clinical applicability of L-asparaginase as a biopharmaceutical to treat blood cancer. Blood Rev 100651.

DALTON TP, SHERTZER HG \& PUGA A. 1999. Regulation of gene expression by reactive oxygen. Annu Ver Pharmacol 39: 67-101.

DE ALBUQUERQUE WANDERLEY MC, NETO JMWD, DE ANDRADE AF, DE MELO RG, DE ARAÚJO VIANA-MARQUES D, BEZERRA RP \& PORTO ALF. 2020. First report on Chlorella vulgaris collagenase production and purification by aqueous two-phase system. Sustain Chem Pharm 15: 100202.

DUARTE AWF, PASSARINI MRZ, DELFORNO TP, PELLIZZARI FM, CIPRO CVZ, MONTONE RC, PETRY MV, PUTZKE J, ROSA LH \& SETTE LD. 2016. Yeasts from macroalgae and lichens that inhabit the South Shetland Islands, Antarctica. Environ Microbiol Rep 8(5): 874-885.

DUARTE AWF ET AL. 2018a. Cold-adapted enzymes produced by fungi from terrestrial and marine Antarctic environments. Crit Rev Biotechnol 38: 600-619.

DUARTE AWF, BARATO MB, NOBRE FS, POLEZEL DA, DE OLIVEIRA TB, DOS SANTOS JA, RODRIGUES A \& SETTE LD. 2018b. Production of cold-adapted enzymes by filamentous fungi from King George Island, Antarctica. Polar Biol 41(12): 2511-2521.

FREIRE RKB, MENDONÇA CMN, FERRARO RB, MOGUEL IS, TONSO A, LOURENÇO FR, SANTOS JHPM, SETTE LD \& PESSOA JUNIOR A. 2020. Glutaminase-free L-asparaginase production by Leucosporidium muscorum isolated from Antarctic marine-sediment. Prep Biochem \& Biotech 1-12.

GABBRIELSON AT, ALZWERI LM \& HELLSTROM WJ. 2017. Collagenase Clostridium histolyticum in the Treatment of Peyronie's Disease: Review of a Minimally Invasive Treatment Option. World J Mens Health 35(3): 134-145.

GARIPOV AR, NESMELOV AA, CABRERA-FUENTES HA \& ILINSKAYA ON. 2014. Bacillus intermedius ribonuclease (BINASE) induces apoptosis in human ovarian cancer cells. Toxicon 92: 54-59.

GHOSH S, ALAM S, RATHORE AS, KHARE SK. 2019. Stability of Therapeutic Enzymes: Challenges and Recent Advances. In: Therapeutic Enzymes: Function and Clinical Implications, Springer, Cham, p. 131-150.

GOCHEVA YG, KRUMOVA ET, SLOKOSKA LS, MITEVA JG, VASSILEV SV \& ANGELOVA MB. 2006. Cell response of Antarctic and temperate strains of Penicillium spp. to different growth temperature. Mycol Res 110: 1347-1354. 
GOEBEL KM \& STORCK U. 1983. Effect of intra-articular Orgotein versus a corticosteroid on rheumatoid arthritis of the knees. Am J Med 74: 124-128.

GOLBABAIE A, NOURI H, MOGHIMI H \& KHALEGHIAN A. 2020. L-asparaginase production and enhancement by Sarocladium strictum: In vitro evaluation of anticancerous properties. J Appl Microbiol 129(2): 356-366.

GONZÁLEZ-TORRES I, PEREZ-RUEDA E, EVANGELISTA-MARTÍNEZ Z, ZÁRATE-ROMERO A, MORENO-ENRÍQUEZ A \& HUERTASAQUERO A. 2020. Identification of L-asparaginases from Streptomyces strains with competitive activity and immunogenic profiles: a bioinformatic approach. Peerj 8: e10276.

hatfield BS ET AL. 2020. Peyronie disease: a clinicopathologic study of 71 cases with emphasis on histopathologic patterns and prevalent metaplastic ossification. Hum Pathol 104: 9-17.

HU Y, ROSEN DG, ZHOU Y, FENG L, YANG G, LIU J \& HUANG P. 2005. Mitochrondrial manganese-superoxide dismutase expression in ovarlan cancer. J Biol Chem 280: 39485-39492.

HÜNKEN M, HARDER J \& KIRST GO. 2008. Epiphytic bacteria on the Antarctic ice diatom Amphiprora Kufferathi Manguin cleave hydrogen peroxide produced during algal photosynthesis. Plant Biology 10: 519-526.

JAIN A, MAL J, MEHNDIRATTA V, CHANDLER R \& PATRA SK. 2011. Study of oxidative stress in vitiligo. Ind J Clin Biochem 26: 78-81.

JIN M, GAI Y, GUO X, HOU Y \& ZENG R. 2019. Properties and applications of extremozymes from deep-sea extremophilic microorganisms: A mini review. Mar Drugs 17(12): 656.

KAN G, WEN H, WANG X, ZHOU T, SHI C. 2017. Cloning and characterization of iron-superoxide dismutase in Antarctic yeast strain Rhodotorula mucilaginosa AN5. J Basic Microbiol 57: 680-690.

KANAI AJ, ZEIDEL ML, LAVELLE JP, GREENBERGER JS, BIRDER LA, GROAT WCD, APODACA GL, MEYERS SA, RAMAGE R \& EPPERLY MW. 2002. Manganese superoxide dismutase gene therapy protects against irradiation-induced cystitis. Am J Physiol Renal Physiol 283: 1304-1312.

KESHERI M, KANCHAN S, RICHA \& SINHA RP. 2014. Isolation and in silico analysis of Fe-superoxide dismutase in the cyanobacterium Nostoc commune. Gene 553: 117-125.

KIM B, RICHARDS SM, GUNN JS \& SLAUCH JM. 2010. Protecting against antimicrobial effectors in the phagosome allows SodCII to contribute to virulence in Salmonella enterica Serovar Typhimurium. J Bacteriol 192: 2140-2149.
KWON MJ, KIM B, LEE YS \& KIM TY. 2012. Role of superoxide dismutase 3 in skin inflammation. J Dermatol Sci 67: 81-87.

LI Z \& DEUTSCHER M. 2004. Exoribonucleases and endoribonucleases. Ecosal Plus 1.

MAKAROV AA, KOLCHINSKY A \& ILINKAYA ON. 2008. Binase and other microbial RNases as potential anticancer agents. Bioessays 30: 781-790.

LOPES AM ET AL. 2017. Therapeutic L-asparaginase: upstream, downstream and beyond. Crit Rev Biotechnol 37(1): 82-99.

MANGIAGALLI M ET AL. 2021. The co-existence of cold activity and thermal stability in an Antarctic GH42 $\beta$-galactosidase relies on its hexameric quaternary arrangement. Febs J 288(2): 546-565.

MARIZCURRENA JJ, MOREL MA, BRAÑA V, MORALES D, MARTINEZLÓPEZ W \& CASTRO-SOWINSKI S. 2017. Searching for novel photolyases in UVC-resistant Antarctic bacteria. Extremophiles 21: 409-418.

MARKLUND S \& MARKLUND G. 1974. Involvement of the superoxide anion radical in the autoxidation of pyrogallol and a convenient assay for superoxide dismutase. Eur J Biochem 47: 469-474.

MARTORELL MM, RUBERTO LAM, DE FIGUEROA LIC \& MAC CORMACK WP. 2019. Antarctic yeasts as a source of enzymes for biotechnological applications. In: Fungi of Antarctica, Springer: Cham, p. 285-304.

MOGUEL IS, YAMAKAWA CK, PESSOA JR A \& MUSSATTO SI. 2020. L-asparaginase production by Leucosporidium scottii in a bench-scale bioreactor with co-production of lipids. Front Bioeng Biotechnol 8.

MORITA A, MINAMI H, SAKAKIBARA N, SATO K \& TSUJI T. 1996. Elevated plasma superoxide dismutase activity in patients with systemic sclerosis. J Dermatol Sci 11: 196-201.

MOROZKINA EV, SLUTSKAYA ES, FEDOROVA TV, TUGAYTI, GOLUBEVA LI \& KOROLEVA OV. 2010. Extremophilic microorganisms: biochemical adaptation and biotechnological application (review). Prikl Biokhim Mikrobiol 46(1): 5-20.

NICHOLSON AW. 1999. Function, mechanism, and regulation of bacterial ribonucleases. Fems Microbiol Rev 23: 371-390.

NÚÑEZ-MONTERO K \& BARRIENTOS L. 2018. Advances in Antarctic research for antimicrobial discovery: a comprehensive narrative review of bacteria from Antarctic environments as potential sources of novel antibiotic compounds against human pathogens and microorganisms of industrial importance. Antibiotics (Basel) 7(4): 90-113. 
OGAKI MB ET AL. 2020. Diversity and bioprospecting of cultivable fungal assemblages in sediments of lakes in the Antarctic Peninsula. Fungal Biol 124(6): 601-611.

PARKER A. 2014. Pattern recognition of temperature trends for Antarctica from linear and nonlinear regression analyses. Nonlinear Engineering 3(3): 179-187.

PARRILLI E \& TUTINO ML. 2017. Heterologous protein expression in Pseudoalteromonas haloplanktis TAC125. In: Psychrophiles: From Biodiversity to Biotechnology, Springer, Cham, p. 513-525.

PIZZINO G, IRRERA N, CUCINOTTA M, PALLIO G, MANNINO F, ARCORACI V, SQUADRITO F, ALTAVILLA D \& BITTO A. 2017. Oxidative stress: harms and benefits for human health. Oxid Med Cell Longev 2017: 1-14.

PRIOR TI, KUNWAR S \& PASTAN I. 1996. Studies on the activity of barnase toxins in vitro and in vivo. Bioconjugate Chem 7: 23-29.

PULSCHEN AA, BENDIA AG, FRICKER AD, PELLIZARI VH, GALANTE D \& RODRIGUES F. 2017. Isolation of uncultured bacteria from Antarctica using long incubation periods and low nutritional media. Front Microbiol 8: 1346.

RATNAM DV, ANKOLA DD, BHARDWAJ V, SAHANA DK \& KUMAR MNVR. 2006. Role of antioxidants in prophylaxis and therapy: a pharmaceutical perspective. J Control Release 113: 189-207.

REDDY GSN, RAJAGOPALAN G \& SHIVAJI S. 1994. Thermolabile ribonucleases from Antarctic psychrotrophic bacteria: detection of the enzyme in various bacteria and purification from Pseudomonas fluorescens. Fems Microbiol Lett 122: 211-216.

ROWE LA, DEGTYAREVA N \& DOETSCH PW. 2008. DNA damageinducer reactive oxygen species (ROS) stress response in Saccharomyces cerevisiae. Free Radic Biol Med 45: 1167-1177.

SANTIAGO M, RAMÍREZ-SARMIENTO CA, ZAMORA RA \& PARRA LP. 2016. Discovery, molecular mechanisms, and industrial applications of cold-active enzymes. Front Microbiol 7: 1408.

SANTOS JAD, MEYER E \& SETTE LD. 2020. Fungal community in antarctic soil along the retreating collins glacier (Fildes Peninsula, King George Island). Microorganisms 8: 1145.

SARMIENTO F, PERALTA R \& BLAMEY M. 2015. Cold and hot extremozymes: industrial relevance and current trends. Front Bioeng Biotechnol 3: 148.

SHIVAJI S, RAO N, SAISREE L, SHETH V, REDDY GSN \& BHARGAVA PM. 1988. Isolation and identification of Micrococcus roseus and Planococus sp. from Schirmacher oasis, Antarctica. J Biosci 13: 409-414.
SHRUTI G, SUKHDEV S \& SINGH KS. 2016. An overview on ribonucleases and their therapeutic effects. Insight Medicine 1: 1-11.

SIDDIQUI KS, WILLIAMS TJ, WILKINS D, YAU S, ALLEN MA, BROWN MV, LAURO FM \& CAVICCHIOLI R. 2013. Psychrophiles Annu Rev Earth Planet Sci 41: 87-115.

SINGH UP, ARDELT W, SAXENA SK, HOLLOWAY DE, VIDUNAS E, LEE H, SAXENA A, SHOGEN K \& ACHARYA KR. 2007. Enzymatic and structural characterization of amphinase, a novel cytotoxic ribonuclease from Rana pipiens oocytes. J Mol Biol 371: 93-111.

SPALLETTI-CERNIA D, SORRENTINO R, GAETANO SD, ARCIELLO A, GARBI C, PICCOLI R, D'ALESSIO G, VECCHIO G, LACCETTI P \& SANTORO M. 2003 Antineoplastic ribonucleases selectively kill thyroid carcinoma cells via caspase-mediated induction of apoptosis. J Clin Endocrinol Metab 88: 2900-2907.

SUKUMAR S, PIJUSH DB \& BRANDES S. 2020. Impact of the advent of collagenase Clostridium histolyticum on the surgical management of Peyronie's disease: a population-based analysis. J Sex Med 17(1): 111-116.

THOMAS DN \& DIECKMANN GS. 2002. Antarctic sea ice - a habitat for extremophiles. Science 295(5555): 641-644.

TOSI S, ANNOVAZZI L, TOSI I, IADAROLA P \& CARETTA G. 2002. Collagenase production in an Antarctic strain of Arthrobotrys tortor Jarowaja. Mycopathologia 153(3): 157-162.

TOSI S, KOSTADINOVA N, KRUMOVA E, PASHOVA S, DISHLIISKA V, SPASSOVA B, VASSILEV S \& ANGELOVA M. 2010. Antioxidant enzyme activity of filamentous fungi isolated from Livingston Island, Maritime Antarctic. Polar Biol 33: 1227-1237.

TURNER J, CHENOLI SN, SAMAH AA, MARSHALL G, PHILLIPS T \& ORR A. 2009. Strong wind events in the Antarctic. J Geophys Res 114: 1-25.

VIMAL A \& KUMAR A. 2020. Antimicrobial potency evaluation of free and immobilized l-asparaginase using chitosan nanoparticles. J Drug Deliv Sci Technol 102231.

WANG Q, WANG Y, HOU Y, SHI Y, HAN H, MIAO M, WU Y, LIU Y, YUE X \& LI Y. 2016. Cloning, expression and biochemical characterization of recombinant superoxide dismutase from Antarctic psychrophilic bacterium Pseudoalteromonas sp. ANT506. J Basic Microbiol 56: 753-761.

WANG Y, HOU Y, NIE P, WANG Y, REN X, WEI Q \& WANG Q. 2019. A novel cold-adapted and salt-tolerant RNase $R$ from Antarctic sea-ice bacterium Psychrobacter sp. ANT206. Molecules 24: 2229-2241. 
WENTZEL LCP, INFORSATO FJ, MONTOYA QV, ROSSIN BG, NASCIMENTO NR, RODRIGUES A \& SETTE LD. 2019. Fungi from admiralty bay (King George Island, Antarctica) soils and marine sediments. Microbial Ecol 77(1): 12-24.

XIE Z, WANG Y, LIU Y \& LIU Y. 2009. Ultraviolet-B exposure induces photo-oxidative damage and subsequent repair strategies in a desert cyanobacterium Microcoleus vaginatus Gom. Eur J Soil Biol 45: 377-382.

YANG G, MOZZICAFREDDO M, BALLARINI P, PUCCIARELLI S \& MICELI C. 2021. An in-silico comparative study of lipases from the Antarctic psychrophilic ciliate Euplotes focardii and the mesophilic congeneric species Euplotes crassus: Insight into Molecular Cold-Adaptation. Mar Drugs 19(2): 67.

YERGEAU E, BOKHORST S, HUISKES AHL, BOSCHKER HTS, AERTS R \& KOWALCHUK GA. 2006. Size and structure of bacterial, fungal and nematode communities along an Antarctic environmental gradient. Fems Microbiol Ecol 59: 436-451.

YOUN H, KIM E, ROE J, HAH YC \& KANG S. 1996. A novel nickelcontaining superoxide dismutase from Streptomyces spp. Biochem J 318: 889-896.

ZHENG Z, JIANG YH, MIAO JL, WANG QF, ZHANG BT \& LI G. 2006. Purification and characterization of a cold-active iron superoxide dismutase from a psychrophilic bacterium, Marinomonas sp NJ522. Biotechnol Lett 28: 85-88.

ZHOU JN, RAUTIO TC, LIU C, XU XY, WANG DQ, GUO Y, ERIKSSON J \& ZHANG H. 2021. Delivery of Protein Kinase A by CRISPRMAX and its effects on breast cancer stem-like properties. Pharmaceutics 13(1): 11.

\section{How to cite}

LIMA IGO, BISPO JRS, AGOSTINHO AYH, QUEIROZ AC, MOREIRA MSA, PASSARINI MRZ, OLIVEIRA VM, SETTE LD, ROSA LH \& DUARTE AWF. 2021. Antarctic environments as a source of bacterial and fungal therapeutic enzymes. An Acad Bras Cienc 94: e20210452. DOI 10.1590/00013765202220210452.

Manuscript received on March 25, 2021;

accepted for publication on August 20, 2021

\section{IGOR G.O. LIMA ${ }^{1}$}

https://orcid.org/0000-0002-0021-7985

\section{JAMES R.S. BISPO ${ }^{1}$}

https://orcid.org/0000-0001-6074-4464

ADSON Y.H. AGOSTINHO ${ }^{1}$

https://orcid.org/0000-0001-7559-2539

\section{ALINE C. DE QUEIROZ}

https://orcid.org/0000-0002-6362-2726

\section{MAGNA SUZANA A. MOREIRA ${ }^{2}$}

https://orcid.org/0000-0002-9979-1994

MICHEL RODRIGO Z. PASSARINI $\left.\right|^{3}$

https://orcid.org/0000-0002-8614-1896

\section{VALÉRIA M. DE OLIVEIRA ${ }^{4}$}

https://orcid.org/0000-0001-8817-4758

LARA D. SETTE ${ }^{5}$

https://orcid.org/0000-0002-5980-3786

\section{LUIZ HENRIQUE ROSA ${ }^{6}$}

https://orcid.org/0000-0001-9749-5182

\section{ALYSSON WAGNER F. DUARTE \\ https://orcid.org/0000-0001-9626-7524}

${ }^{1}$ Universidade Federal de Alagoas, Complexo de Ciências Médicas e Enfermagem, Campus Arapiraca, Av. Manoel Severino Barbosa, s/n, Bom Sucesso, 57315-226 Arapiraca, AL, Brazil

${ }^{2}$ Universidade Federal de Alagoas, Instituto de Ciências Biológicas e da Saúde, Av. Lourival Melo Mota, s/n, Tabuleiro do Martins, 57072-900 Maceió, AL, Brazil

${ }^{3}$ Universidade Federal da Integração LatinoAmericana, Av. Silvio Américo Sasdelli, 1842, Itaipú A, 85866-000 Foz Do Iguaçu, PR, Brazil

${ }^{4}$ Universidade Estadual de Campinas, Centro Pluridisciplinar de Pesquisas Químicas, Biológicas e Agrárias, R. Alexandre Cazellato, 999, Betel, 13148-218 Paulínia, SP, Brazil

${ }^{5}$ Departamento de Biologia Geral e Aplicada, Instituto de Biociências, Universidade Estadual Paulista Júlio de Mesquita Filho, Av. 24 A, 1515, Bela Vista, 13506-752 Rio Claro, SP, Brazil

${ }^{6}$ Universidade Federal de Minas Gerais, Instituto de Ciências Biológicas, Av. Presidente Antônio Carlos, 6627, Pampulha, 31270-901 Belo Horizonte, MG, Brazil

Correspondence to: Alysson Wagner Fernandes Duarte E-mail: alysson.duarte@arapiraca.ufal.br

\section{Author contributions}

IGO Lima: Conceptualization, Methodology, Wrote the paper; JRS Bispo and AYH Agostinho: Contributed data and wrote the paper; AC Queiroz, MSA Moreira, MRZ Passarini, VM Oliveira, LD Sette and LH Rosa: Writing-review and editing; AWF Duarte: Conceptualization, Supervision, Writing, Review and Editing. All authors discussed the results and approved the final version of the paper.

\section{(cc) BY}

